plasma leptin determination. Five of the 11 patients were studied by a hyperinsulinic euglycemic clamp with [6,6-2H2] glucose used as tracer, and substrate oxydation measured by indirect calorimetry (IC).

The Wilcoxon test was used to compare results (mean \pm SEM) before and 12 months after GH treatment. These results showed that in spite of a significant IGF1 increase $(158 \pm 17$ versus $77 \pm 9 \mathrm{ng} / \mathrm{ml})$, neither the body weight $(70 \pm 6$ versus 71 $\pm 6 \mathrm{~kg}$ ), nor the fat mass percentage ( $30 \pm$ 2 versus $31 \pm 2 \%$ ) nor the leptinemia (12 \pm 3 versus $13 \pm 3 \mu \mathrm{g} / \mathrm{L}$ ) were modified. Post-prandial endogenous glucose production $(10.9 \pm 0.6$ versus $11.3 \pm 0.4$ $\mathrm{mg} / \mathrm{kg} / \mathrm{min}$ ) and insulin stimulated glucose disappearance $(40 \pm 3$ versus $47 \pm 3$ $\mathrm{mg} / \mathrm{kg} / \mathrm{min}$ ) were not significantly modified by $\mathrm{GH}$ treatment. The $\mathrm{IC}$ measures showed a more pronounced $(P<0.05)$ protide oxydation inhibition under insulin perfusion $(0.7 \pm 0.1$ versus $1.0 \pm 0.1$ $\mathrm{mg} / \mathrm{kg} / \mathrm{min}$ ). Glucose and lipid oxydation were not significantly changed.

In conclusion, a complete GH substitution of GH deficient patients had no effect on body composition and did not seem to have any deleterous effect on glucose metabolism and insulinosensitivity.

\section{Control of glucose-6-phosphatase in the small intestine of fasted and diabetic} rats. N. Bruni, F. Rajas, S. Tarpin, C. Zitoun, G. Mithieux (Inserm U. 449, Faculté de Médecine RTH Laënnec, 69372 Lyon cedex 08, France).

Glucose-6-phosphatase (Glc6Pase) is the last enzyme of gluconeogenesis and glycogenolysis. In agreement with the concept that only the liver and kidney express Glc6Pase, it has been recently reported, using a RT-PCR approach, that Glc6Pase mRNA was not detectable in nine other tissues. Using the same approach, we demonstrated the presence of Glc6Pase mRNA in the duodenum (DUO) and jejunum (JEJ) of adult rats (10-12 weeks), while Glc6Pase mRNA was not detected in the stomach, ileum, colon, brown adipose tissue, adrenals and bladder. We studied the effect of fasting and diabetes on Glc6Pase mRNA (by northern blot) and specific Glc6Pase activity in the small intestine in rats. The amount of Glc6Pase mRNA increased by eight times and six times $(P<0.01)$ in DUO and JEJ in streptozotocin diabetic rats. It returned to normal levels after insulin treatment for $10 \mathrm{~h}$. Glc6Pase activity was increased by $300 \%$ in DUO $(2.6 \pm 0.8$ versus $0.83 \pm 0.09 \mathrm{U} / \mathrm{g}$ wet tissue, mean \pm S.E.M, $n=4, P<0.05$ ) and JEJ $(1.9 \pm 0.3$ versus $0.63 \pm 0.03 \mathrm{U} / \mathrm{g}$, $P<0.01)$ in diabetic rats as compared to normal rats. The amount of Glc6Pase mRNA increased by eight and seven times in DUO and JEJ of 48 -h-fasted rats. It returned to normal levels in both tissues after refeeding for $7 \mathrm{~h}$. Glc6Pase activity was significantly increased in fasted rats $(2.5 \pm 0.6$ and $1.3 \pm 0.2 \mathrm{U} / \mathrm{g}$ in DUO and JEJ, means \pm S.E.M., $n=5, P<0.05$ versus normal fed rats). In addition, Glc6Pase mRNA and activity were also expressed in ileum during fasting $(1.3 \pm 0.4 \mathrm{U} / \mathrm{g})$. Glc6Pase mRNA and activity were also demonstrated in the human small intestine. In the human colon carcinoma cell line Caco-2, Glc6Pase is only expressed 15 days after the confluence of cells, in agreement with the state of differenciation of Caco- 2 cells in the enterocytes for glucose metabolism. Thus, the small intestine might possess the capacity to produce endogenous glucose in portal blood. This should have important implications in various metabolic situations.

\footnotetext{
Assessment of insulin sensitivity from plasma insulin and glucose in the fasting or post oral glucose-load state. A. Avignon, A. Radauceanu, L. Monnier (Metabolic disease department, Lapeyronie hospital, 34295 Montpellier cedex 5, France).
} 
Insulin resistance is increasingly being recognized as an important factor in the pathogenesis of ischemic heart disease. Estimating insulin sensitivity is time consuming and requires considerable expertise and equipment. Hence, we compared two insulin sensitivity indexes derived from plasma insulin (I) and glucose (G) in the basal state $\left[\right.$ Sib $=10^{8} /$ (I.G.VD)] and at the second hour (I2-h and G2-h) of an OGTT [ Si-2-h= $\left.10^{8} /(\mathrm{I} 2-\mathrm{h} . \mathrm{G} 2-\mathrm{h} . \mathrm{VD})\right]$ with measurements of insulin sensitivity using either the insulin modified FSIVGTT [ $S i_{(I V G T T)}, 47$ subjects] or the euglycemic clamp [ $S i_{(C L A M P}, 10 \mathrm{sub}$ jects]. VD was an estimate of the apparent glucose distribution volume.

$S i_{(I V G T T)}$ was found to be highly correlated $(P \leq 0.0001)$ with $S i b$ and $S i-2-h$ in the overall population $(r=0.827$ and $r=$ 0.893 , respectively). $S i-2-h$ was also highly correlated with $S i_{(I V G T T)}$ in subjects with normal glucose tolerance (NGT, $n=31$ ), in those with impaired glucose tolerance (IGT, $n=10$ ) and in those with type 2 diabetes $(n=6)$. A close correlation $(\mathrm{r}=$ $0.897, P \leq 0.0001$ ) was found between $\mathrm{Sib}$ and $S i_{(C L A M P)}$. The slopes of the correlation lines of $S i-2-h$ against $S i_{(I V G T T)}$ were compared between the three subgroups of subjects: NGT, IGT and overt type 2 diabetes, but no differences were observed.

For all these reasons, calculations of sensitivity indexes from plasma glucose and insulin concentrations in the basal state and during a conventional 2-h oral glucose tolerance test appear to be useful for coupling in the same simple and single test both a determination of glucose tolerance and an estimate of insulin sensitivity.

Metabolic fate of starch ingested in a complex meal. N. Noah ${ }^{\mathrm{a}, \mathrm{b}}$, Y. Zaïr ${ }^{\mathrm{b}}, \mathrm{P}$. Maugère $^{b}$, M. Krempf ${ }^{b}$, M. Champ ${ }^{a, b}$ (Inra, rue de la Géraudière, BP 71627 , 44316 Nantes cedex 03; ' CRNH HôtelDieu, place A. Ricordeau 44093 Nantes cedex 01, France).
Introduction: While some starchy foods are recommended in the diets of diabetics or sportsmen, their metabolic fates are still unclear.

Aim of the study: To evaluate the splanchnic captation of glucose coming from the digestion of a ${ }^{13} \mathrm{C}$-naturally enriched starch in humans, and its use at peripheral levels.

Methods: Six volunteers were infused with a tracer solution $\left(6,6^{2} \mathrm{H}_{2}\right.$-glucose $)$ at a constant rate in the arm in order to calculate the glucose flux. Blood samples were collected in the other arm. Two hours after the beginning of the infusion, the subjects ingested a balanced meal containing pregelatinized maize starch (50 g glucose-equivalent). Respiratory exchanges were analysed using indirect calorimetry and $\mathrm{CO}_{2}$-expired samples were regularly collected during the $8-\mathrm{h}$ period. Mass spectrometry techniques were used to analyse infused and ${ }^{13} \mathrm{C}$ exogenous glucose in plasma, and expired ${ }^{13} \mathrm{CO}_{2}$. Results were expressed as mean \pm standard error of the mean.

Results: Postprandial glycemia and insulinemia maxima at $30-45 \mathrm{~min}$ were, respectively, $0.98 \pm 0.1 \mathrm{~g} / \mathrm{L}$ and $28 \pm$ $10 \mathrm{mUJ} / \mathrm{L}$. Glucose flux, $13 \pm 1 \mathrm{mmol} / \mathrm{kg} /$ min at basal state, peaked at 20-22 $\mathrm{mmol} / \mathrm{kg} / \mathrm{min}$ (at $30 \mathrm{~min}$ ) and returned to the basal value after $6.5 \mathrm{~h}$. At that time, $89 \pm 2 \%$ of the exogenous glucose ingested arrived at the peripheral level. Endogenous glucose production was decreased by $25 \%$. Exogenous glucose, however, probably partly recycled, still represented $25 \%$ of the circulating glucose $8 \mathrm{~h}$ after the meal. The total quantity of dietary glucose oxidized was $20.1 \pm$ $1.3 \mathrm{~g}$.

Conclusion: The rate of absorption, slower in the case of starch, does not seem to affect splanchnic captation. The glucose reaching the peripheral level may have been stored, under the form of neoglucogenic substrates or not, and then 